\title{
Factors Driving the Adoption of E-banking Services Based on the UTAUT Model
}

\author{
Gladys Chikondi Daka ${ }^{1} \&$ Jackson Phiri ${ }^{2}$ \\ ${ }^{1}$ Graduate School of Business, University of Zambia, Lusaka, Zambia \\ ${ }^{2}$ School of Natural Sciences, Department of Computer Sciences, University of Zambia, Lusaka, Zambia \\ Correspondence: Gladys Chikondi Daka, Graduate School of Business, University of Zambia, Lusaka, Zambia. \\ E-mail: daka.gladys@yahoo.com
}

Received: March 10, 2019

doi:10.5539/ijbm.v14n6p43

\author{
Accepted: April 23, 2019 \\ Online Published: May 16, 2019 \\ URL: https://doi.org/10.5539/ijbm.v14n6p43
}

\begin{abstract}
E-banking has become one of the most popular methods that has experienced considerably great attention in the financial services studies in the last few years. E-banking enables customers of the bank to conduct a range of financial services via the internet portal. It provides a solution in driving formal banking services uptake in the most cost-effective way, it has great benefits to both the customers as well as the banks i.e. convenience, cost reduction, ease and is an effective marketing tool. This research was conducted to determine the underlying factors that drive the adoption of e-banking services based on the UTAUT model and to recommend solutions that will address the identified underlying factors. A baseline study involving 313 respondents was undertaken with the sample consisting of Clients from the top five (5) banks in Zambia with the best digital capabilities. Questionnaires were administered to these Clients through purposive sampling to get information on their views on Internet banking services. Data was analysed using SPSS descriptive analysis. The results of the study revealed that the UTAUT factors; performance expectancy (PE), effort expectancy (EE), facilitating conditions (FC) and behaviour intention (BI) have a significant impact in the adoption of e-banking services. Social influence (SI) was non-significant to the user's intention to adopt e banking services.
\end{abstract}

Keywords: factors, adoption, E-banking, UTAUT model

\section{Introduction}

Technology has not been fully accepted as another economical way of doing banking by bank Clients in Zambia (Nuwagaba \& Ngoma, 2014). Forty -one percent (41\%), above three and a half million (3.5m) million Zambian adults are financially excluded, meaning these people do not have the capacity nor the ability to access financial services/products. Digital platforms provide an opportunity to accelerate financial inclusion. The ZICTA ICT survey report 2015, indicates that the proportion of people in the Country cognizant of the availability of technological financial services and products was $45.9 \%$. However, only $30 \%$ of the people mindful of the digital platforms actually utilized the services to pay for goods/services and money transfer.

There is still more room to exploit the benefits that the digital technologies can provide to further reduce costs and widen the reach of the formal financial sector (2017-2022 National Financial Inclusion Strategy). To achieve this, it is inevitable to understand the fundamental factors that drive the adoption of digital / e-banking services.

In-spite of the many studies undertaken on the adoption of the e-banking platforms globally, limited research has been conducted in Zambia specifically. Saxena (2018) indicates that the adoption and use of electronic banking remains fertile for further academic research. From the researcher's literature review knowledge, no research has been undertaken in Zambia using the Unified Theory of Acceptance and Use of Technology, an all-inclusive model as the same amalgamates the theories of eight models that have previously been used to explain technology acceptance. These theories include; Theory of planned behavior (TPB), Diffusion Innovation theory (DIT), Theory of Reasoned Action (TRA) Social Cognitive Theory, Personal Computer Use (PCU), Technology Acceptance Model (TAM), Motivational Model (MM) and Combined theory of planned behavior. The UTAUT theory has also been proven to explain for $70 \%$ of the variance in Behavioral Intention (BI) and $50 \%$ in actual usage. 
This study is significant in the determination of the validity of the Unified Theory of Acceptance and Use of Technology in a developing Country. This Model has not been extensively validated since it was initially proposed by Venkatesh et al. (2003). This study will be of great help in the driving of the e-banking adoption which will ultimately accelerate the financial inclusion journey in Zambia. The study will also contribute to the limited e- banking adoption studies in Zambia.

\section{Literature Review}

Electronic banking has become one of the common methods used by majority of the banks to provide services to their Client in Zambia. Electronic banking refers to the mode by which banks use electronic channels to offer bank products and services to clients (Al-Smadi, 2012). The Basel committee report defines e-banking as the provision of retail and small value banking products and services through electronic channels as well as large value payments and other wholesale banking services delivered electronically. Electronic banking is a new concept of conducting banking transactions and has captured the interest of many banks as an alternate way to traditional banking. It is a highly information intensive activity that depends heavily on information technology to acquire, process and deliver financial information to all users (Alkailani, 2016). It provides customers with a variety of services which include; bill payments, balance enquiry, telegraphic transfers, forex, loan repayments, statements account opening etc. (Alalwan et al., 2014). E banking has remained unexploited by many banks to maximise its full potential, this provides more opportunity for banks to move its Clients to the e- platforms. Unavailability of cyber security and cordiality of internet in banking significantly affects the customer trust and makes customer reluctant to access their bank accounts electronically (Hussain et al., 2017). Other factors that have been sighted to being of great challenge by authors is the unreliability of the system which have proved to be unstable arising from technological challenges, links \& Network problems these are evident from the number of countless outages that users experience due to connectivity issues (Hussain et al., 2017). Extant literature has identified a number of factors that may lead to a low adoption of technology via various technology adoption theories i.e. Technology Acceptance Model (TAM), which highlights perceived ease of use, perceived usefulness as factors affecting the adoption of e-banking. Varaprasad et al., 2013, in their study on internet banking in a developing Country revealed that perceived usefulness, perceived ease of use, perceived risk, relative advantage, and conspicuousness are significant drivers of internet banking adoption. Similar to the findings of Varaprasad et al., 2013, Mwiya et al., 2017 study indicate that perceived usefulness, perceived ease of use and trustworthiness are associated with attitude toward e-banking use. Md NOR et al., 2011 adds that the key determinants to an individual's intention to use electronic banking services includes; perceived usefulness, security, compatibility, cost and technical resources. Vinayak and Jindal 2013 in the study on the Drivers of Customers Adoption of E banking: An empirical Investigation, concludes that perceived usefulness and perceived ease of use are the primary causes of the adoption of e-banking services which ties with the Technology Acceptance Model (TAM) David et al., 1989. Clients will only use e-banking services the more if they perceive it to be relatively useful in terms of convenience, flexibility and ease of use (Moodley \& Govender, 2016). More Scholars (Lin et al., 2015; Mbokoroh, 2015) have alluded that perceived usefulness, perceived ease of use, perceived credibility, perceived behavioral control, subjective norms and attitude towards the adoption to be drivers of internet banking adoption. Lusaya and Kalumba (2018), adds that e banking usage depends on the availability of e- banking information. Education also plays a critical role in the actual adoption of the services.

The above studies have all made considerable contributions to understand the factors driving the adoption of $\mathrm{e}$ banking. However, there has been no consensus on what is really the important factors from the customer perspective that policy makers should be conversant of in the Zambian market and developing African Countries which is farfetched in technology development and adoption.

\section{Theoretical Frameworks}

Over the past years, studies in technology adoption have developed many theories and models to elucidate and determine the factors that drive e-banking adoption. The models include; Innovation Diffusion Theory (IDT), Theory of Planned Behavior (TPB), Theory of Reasoned Actions (TRA), Technology Acceptance Model (TAM),an extensively used model in IB adoption studies, Perceived Characteristics of Innovation (PCI), Decomposed Theory of Planned Behavior (DTPB), Theory of Perceived Risk (TPR), Theory of Innovation Resistance (TIR) and the Unified Theory of Acceptance and Use of Technology (UTAUT).The researcher opted to use the UTAUT model for this study as the same explains $70 \%$ of the difference in behavior intention and close to $50 \%$ in the usage.

\subsection{Unified Theory of Acceptance and Use of Technology}

The unified theory of acceptance and use of technology (UTAUT) Model was formulated by Venkatesh et al., 
2003 in a quest to harmonize previous technology adoption models. The Model has four main constructs (performance expectancy, effort expectancy, social influence and facilitating conditions) considered to be the primary determinants of behavior intention and the ultimate usage of the system. The theory also makes cognizant of the role of the demographics (gender, age, experience, and voluntariness of use) which are considered to be moderators to the four constructs. The current study focuses on the four main constructs and thus it should be noted that the moderating factors were not tested in this study. Although the UTAUT Model has been widely used across various studies in technology acceptance research, no study to date has been undertaken

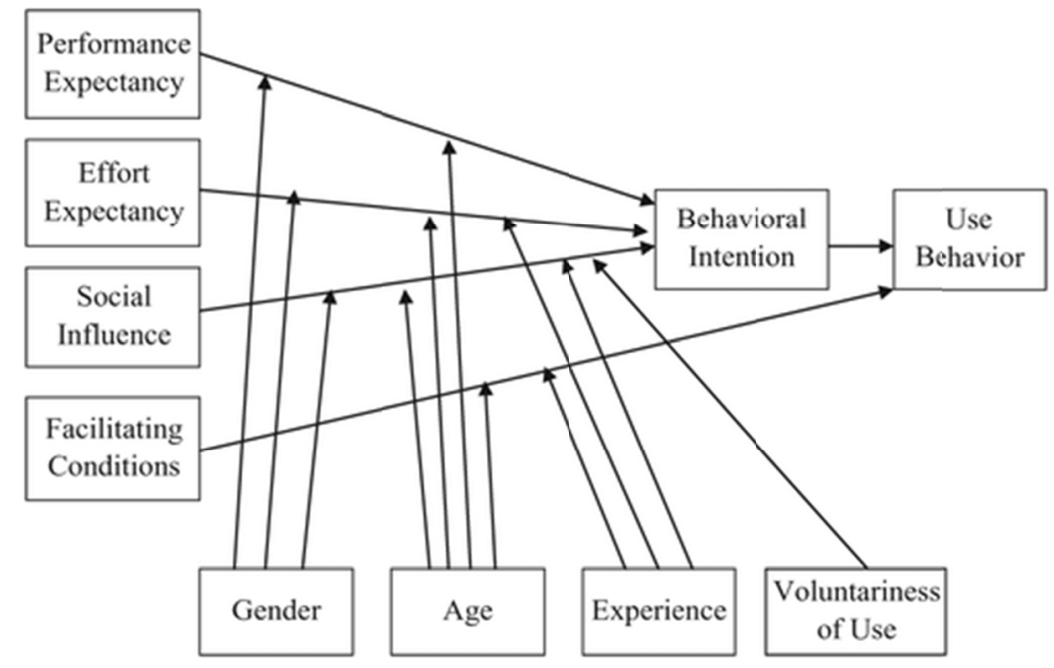

in Zambia using this model.

Figure 1. UTAUT (Venkatesh, Morris, Davis, \& Davis, 2003)

This research has adapted the UTAUT model and therefore employs performance expectancy, effort expectancy, social influence and facilitating conditions as Independent variables to determine customers attitude towards the adoption of e banking services. According to Tarhini et al. (2016), UTAUT has demonstrated to be an effective and stable model used to predict technology acceptance. The theory is one of the most reliable and trusted theory thus becoming one of the most widely used theories (Venkatesh et al., 2003). The UTAUT model is able to explain 70 percent of the variance in usage intention, which is significant compared to the actual eight models used to build it (Martins et al., 2014).

\subsection{Performance Expectancy}

Performance expectancy (PE) is defined as "the degree to which the user expects that using the system will help him or her to attain gains in job performance" (Venkatesh et al., 2003). It is defined as one of the most important predictors of the intension to use technology (Venkatesh et al., 2003). People are expected to adopt new technologies if they believe the same will help them to do their jobs. Prior studies have indicated that performance expectancy positively affects the user's intention to adopt internet banking.

Therefore, in this study the researcher will check to see if users think IB is useful in their day to day jobs. If respondents think IB is useful then there is a high likelihood of them adopting the system.

\subsubsection{Effort Expectancy}

It can be defined as, "the degree of ease of use if Technology" (Venkatesh et al., 2003). Yousafzai, 2012 suggests that if an individual perceives IB to be easy to use he will have a high perception of its performance. Previous empirical studies, have demonstrated that effort expectancy would influence the consumers' attitude of use in both mandatory and voluntary usage (Chi-Yo Huang and Yu-Sheng Kao 2015).

In this study the researcher will check to see if users think IB is easy to use. If respondents think IB is easy to use then there is a high likelihood of them adopting the system.

\subsubsection{Social Influence}

SI reflects the influence of people around us concerning the use of IB (Yousafzai, 2012). Social influence (SI) can be classified into two parts: the social norms and the critical mass. The social norms include two different 
influences: the informational influence and the normative influence. The informational influence refers to people's obtaining of information from other people. The normative influence refers to a user's conformation to the expectation of other people to gain a reward or avoid a punishment (Huang \& Kao 2015). Venkatesh et al. (2003) defines social influence as; "the degree of importance being recognized by others to use a novel technology." Various scholars (Tarhini et al., 2016; Mborokoh, 2015) revealed that SI was an important driver of Behavior Intention. Thus, in this study the researcher will be analyzing if the respondents are influenced in any way by people around them to adopt IB. If the respondents are easily influenced then they are more likely to adopt IB.

\subsubsection{Facilitating Conditions}

Facilitating conditions (FC) is "the degree to which an individual believes that an organizational and technical infrastructure exists to support use of the system." (Venkatesh, 2003). According to Huang and Kao 2015, previous researches on factors influencing acceptance of some specific technology have exhibited that facilitating conditions have a significant impact on innovative technology adoption and usage behaviors. The researcher will be investigating if the respondents have resources to use Internet Banking. Availability of resources will enable Clients to adopt e-banking.

\subsubsection{Behavior Intention}

Behavioral intention refers to the degree to which a person has made up a conscious decision to use of not to use Internet Banking (Huang and Kao, 2015). Many prior researchers have discovered that behavioral intention is substantial in the actual usage behavior. The researcher will review respondents plan to use the Internet banking platform in the near future.

\section{Methodology}

A purposive sample of minimum of 267 respondents was arrived at using a scientific method of sample determination for the quantitative study. The researcher's strategy was to ask all respondents a primary question to know whether they operate personal account or sole proprietorship/enterprise account and also made a distinction between the Internet banking users to understand what actually influences them and the non-internet banking users to understand what affects their adoption. Respondent that have corporate account were asked no further questions, hence, leading to some form of randomization in actual selection of respondents used for the study. The researcher administered questionnaires to respondents by standing at the entrance of the banks' branches and at the ATM terminals of the Banks in Lusaka to purposively access individual customers of the banks. 313 questionnaires in all were administered to the respondents of the five banks across.

The researcher used the quantitative method of study for this research in view of the following factors; A number of reviewed literatures under this study have been that of quantitative in nature (B Mwiya et al., 2017, Huang and Kao 2015, Paul Juinn Bing Tan,2013). Quantitative method proves to be more appropriate for the study as it involves the testing of the theory constructs.

Non- probability sampling was adopted for this research. One of the shortcomings is the inability to generalize the findings from research because the data is not a representation of the whole population under study. However, these shortcomings were mitigated by selecting a sample frame based on the below sampling criterion:

\section{Respondents must have a bank account with any bank in Zambia}

Quantitative data was analyzed with the help of spread-sheets (e.g. Excel) and the Statistical Package for Social Sciences (SPSS) version 16 to perform various statistical analysis. Descriptive Statistics analysis were performed on survey data using SPSS version 16. This data has been summarized by presenting it in graphs and tables. Five (5) major banks were selected, Barclays Bank, First National Bank, Stanbic Bank, Standard Chartered Bank and Zambia National Commercial Bank being the largest, oldest banks and highly digitized banks in Zambia and most importantly the five banks offer similar internet banking products. Since the functionalities' deployed by these banks are almost similar and most Clients are multi banked, the study used customers of these five banks that actually are account holders with these banks to conduct the study. However, due to the large population size of customers of the five banks, the study employed a mathematical formula to correctly come up with a suitable sample for the study. The ideal sample for infinite populations as outlined by (Cochran, 1977) is given as:

$$
n o=\left(z^{\wedge} 2 \times p(1-p)\right) / e^{\wedge} 2
$$

Where;

no is the sample size

$\mathrm{Z}$ is the two tailed area under the normal curve 
e is the acceptable sampling error

where $\alpha=0.05$ and the $\mathrm{z}$ value is 1.96

$\mathrm{p}$ is the population of a proportion with a desired attribute (assumed to be 0.5 which maximizes the sample size to be determined) With an acceptable sampling error of $6 \%$, the sample size determined is as

$$
\text { no }=(1.962 \times 0.5(1-0.5)) /\left((0.06)^{2}\right)=267
$$

Therefore, a purposive sample of 267 respondents will be selected for the quantitative study. 313 questionnaires in all were administered to the respondents of the five banks across.

\section{Results}

The total respondents that were used in this study were 313 that were drawn from the top 5 banks in Zambia (Zambia National Commercial Bank, Standard Chartered Bank, First National Bank, Barclays Bank and Stanbic Bank). Of the 313 respondents, 233 (74\%) of the respondents were actual Internet Banking users and 80 (26\%) were non IB users. Figure 2 below shows the percentage of the IB users and non-users. Of the total respondents $54 \%$ (169) were male and 46\% (144) were female. Majority of the respondents fell in the age bracket of 21 to 30 accounting for $42 \%$ of the respondents. 244 (78\%) of the respondents were in formal employment such as salaried workers thus the need to use electronic banking platforms.

Despite the many obstructs in the adoption of Internet banking, there are many benefits and ultimate drivers in the adoption of internet banking. In the case of Zambia banking system there has been a shift in the digital uptake signifying a more than 50\% increment in the use of e-banking channels (Mwiya, et.al, 2017).

Performance Expectancy: It relates to the degree to which individuals using Internet banking believes that the use of the system will help in the attainment of gains in the job performance. In this study the factors relating to performance expectancy mainly reviewed the benefits/ relative advantage that internet banking provides.

Table 1. Performance expectancy

\begin{tabular}{|l|c|c|c|c|c|}
\hline \multicolumn{2}{|l|}{ Performance Expectancy Statistics } & & & \\
\hline & $\begin{array}{l}\text { Internet banking } \\
\text { would be useful } \\
\text { in carry out my } \\
\text { task }\end{array}$ & $\begin{array}{l}\text { Use of I.B would } \\
\text { enable me conduct } \\
\text { tasks more quickly }\end{array}$ & $\begin{array}{l}\text { Use of I.B } \\
\text { would increase } \\
\text { my productivity }\end{array}$ & $\begin{array}{l}\text { Use of I.B would } \\
\text { improve } \\
\text { performance }\end{array}$ \\
\hline m & Valid & 313 & 313 & 313 & 313 \\
\hline Median & Missing & 0 & 0 & 0 & 0 \\
\hline Mode & & 5 & 5 & 4 & 5 \\
\hline
\end{tabular}

Note. N-Number of responses; Response measurements, 1-strongly disagree, 2-Dis -agree, 3-Neutral, 4-Agree and 5-strongly agree.

Respondents in this study were asked as to whether they think internet banking was useful and beneficial in carrying out their tasks and the descriptive results gives a median of 4 and 5 and mode of 5 . This demonstrates that the majority of the respondents strongly agreed that IB is useful in carrying out their tasks. Therefore, performance expectancy is one of the key drivers in the adoption of e-banking system in Zambia. The results are consistent with that of other researchers (Mwiya,2017; AlKailani,2016 and Mbrokoh,2015) were perceived usefulness and performance expectancy were indicated as key determinants in the adoption of e-banking services.

Effort Expectancy. Clients will choose to use Internet banking system if its comfortable to operate and easy to learn how to use. The ease of use of the system might be important aspect which encourages customers to use Internet banking (Mbrokoh,2015).

Table 2. Effort expectancy

\begin{tabular}{|l|l|c|c|c|c|}
\hline \multicolumn{2}{|l|}{ Effort Expectancy Statistics } & & & \\
\hline & $\begin{array}{l}\text { Interaction with } \\
\text { I.B is clear and } \\
\text { understandable }\end{array}$ & $\begin{array}{l}\text { It's easy to become } \\
\text { skillful at using I.B }\end{array}$ & $\begin{array}{l}\text { Find I.B easy to } \\
\text { use }\end{array}$ & $\begin{array}{l}\text { Learning to operate } \\
\text { I.B is easy for me }\end{array}$ \\
\hline $\mathrm{N}$ & Valid & 313 & 313 & 313 & 313 \\
\hline & $\begin{array}{l}\text { Missin } \\
\mathrm{g}\end{array}$ & 0 & 0 & 0 & 0 \\
\hline Median & & 4 & 4 & 4 & 5 \\
\hline Mode & & 4 & 4 & 5 & 5 \\
\hline
\end{tabular}

Note. N-Number of responses; Response measurements, 1-strongly disagree, 2-Dis-agree, 3-Neutral, 4-Agree and 5-strongly agree. 
Table 3, shows the results of the respondents that were asked as to whether they think internet banking was easy to use and the descriptive results gives a median of 4 and mode of 4 and 5. From the above results, majority of the respondents agree that IB is clear and understandable. This may be the reason why we had the majority of the correspondents that is $74 \%$ using the platform. This result is consistent with that of other researchers (B. Mwiya,2017; Alkailani,2016 and Venkatesh et al., 2003) were perceived ease of use and effort expectancy were indicated as factors influencing the adoption of e-banking services.

Social Influence: Some researchers have explored the concepts of social influence and proved the influences of social influence on shaping user's behavior. Venkatesh et al. 2003 defined social influence as the degree of importance being recognized by others to use a novel technology. The social influence construct consists of three variables: the subjective norm, the social factor, and the image. (1) Subjective norm: the subjective norm is the perceived social pressure to perform or not to perform the behavior. In this research, the subjective norm is the perceived social pressure to use IB. (2) Social factor: the social factor is an individual's internalization from the social system's subjective culture and particular interpersonal agreements that the individual in particular social situation has made with others. (3) Image: the image is defined as the degree to which an individual identifies that the use of an innovative technology can enhance an individual's status in his or her social organization.

Table 3. Social influence factors

\begin{tabular}{|c|c|c|c|c|c|c|}
\hline \multicolumn{7}{|c|}{ Social Influence Statistics } \\
\hline & & $\begin{array}{l}\text { People who } \\
\text { Influence my } \\
\text { behavior think } \\
\text { I should use IB }\end{array}$ & $\begin{array}{l}\text { People } \\
\text { important to } \\
\text { me think I } \\
\text { should use IB }\end{array}$ & $\begin{array}{l}\text { People who } \\
\text { use IB have } \\
\text { high } \\
\text { prestige }\end{array}$ & $\begin{array}{lr}\text { IB } & \text { users } \\
\text { have high } \\
\text { profile }\end{array}$ & $\begin{array}{l}\text { IB is a } \\
\text { status } \\
\text { symbol }\end{array}$ \\
\hline $\mathrm{N}$ & Valid & 313 & 313 & 313 & 313 & 313 \\
\hline & Missing & 0 & 0 & 0 & 0 & 0 \\
\hline Median & & 3 & 4 & 3 & 3 & 3 \\
\hline Mode & & $3^{a}$ & 4 & $2^{\mathbf{a}}$ & 2 & 2 \\
\hline
\end{tabular}

Note. N-Number of responses; Response measurements, 1-strongly disagree, 2-Dis -agree, 3-Neutral, 4-Agree and 5-strongly agree.

From the results of the study the social influence factor will be classified into two parts that is the subjective norm looking at the first two questions and the image for the last 3questions. On the subjective norm the median was 3 and 4 and the mode was 3 and 4 basically this indicates that people were neutral about the subjective norm and for the image the Median was 3 and the mode was 2 . The results indicate that the respondents disagreed with the image category of the Social Influence factors. From the general outcome of the study it can be concluded that Social Influence is not a major driver for the adoption of e-banking services in Zambia. This is in contradiction with other research findings (Venkatesh et.al,2003), (Mborokoh, 2015), (Huang and Kao,2014) who found that social influence is a positive predictor of consumers intention to adopt Internet Banking. This may indicate that respondents that were used for the study were not driven by societal opinions. This is in agreement with other researchers i.e. Naranjo-Zolotov and Tiago Oliveira (2018) who found social influence to have no significant effect on the of intention to use Internet Banking.

Facilitating Conditions: Oliveria and Zolotov (2018) indicate that an individual with easy access to resources like computers, smartphones, internet connection, support chat rooms, phone line or other favorable conditions will increase his or her intention to use e-channels. Knowledge will also increase an individual's intention to use internet banking.

Table 4. Facilitating conditions

\begin{tabular}{|c|c|c|c|c|c|c|}
\hline \multicolumn{7}{|c|}{$\begin{array}{l}\text { Facilitating } \\
\text { Statistics }\end{array}$} \\
\hline & & \begin{tabular}{|lr} 
I have \\
resource to \\
use IB
\end{tabular} & $\begin{array}{l}\text { I have } \\
\text { knowledge } \\
\text { to use IB }\end{array}$ & $\begin{array}{l}\text { Help/guidanc } \\
\text { e available } \\
\text { on using IB }\end{array}$ & $\begin{array}{l}\text { IB platforms have } \\
\text { most of the service I } \\
\text { need from the branch }\end{array}$ & $\begin{array}{l}\text { I am aware of } \\
\text { the services and } \\
\text { activities on IB }\end{array}$ \\
\hline \multirow[t]{2}{*}{$\mathrm{N}$} & Valid & 313 & 313 & 313 & 313 & 313 \\
\hline & Missing & 0 & 0 & 0 & 0 & 0 \\
\hline Median & & 4 & 4 & 4 & 4 & 4 \\
\hline Mode & & 5 & 5 & 4 & 4 & 4 \\
\hline
\end{tabular}

Note. N-Number of responses; Response measurements, 1-strongly disagree, 2-Dis -agree, 3-Neutral, 4-Agree and 5-strongly agree. 
The results of the study indicate that respondents have the resources to enable them adopt e-banking services. Previous researches have indicated that facilitating conditions are strong predictors which can be used for forecasting technology acceptances and usages Huang and Kao (2014). Mbokoroh, 2015 explains that Internet Banking users require to have skills such as configuring and operating computers and connecting to the Internet as well as financial resources to bear operational and transactional cost. Most of the users strongly agreed on the availability of the resources to use IB. Therefore, facilitating conditions have a significant impact on the behavior intention to use Internet Banking.

Behavior Intention (BI): BI is considered to be a direct driver of usage behavior and gives a sign about an individuals' readiness to perform a specific behavior. There is considerable evidence of the substantial impact of BI on actual usage (e.g. Venkatesh et al., 2003 Tarhini et al., 2013b).

Table 5. Behavior intention

\begin{tabular}{|l|c|c|c|c|c|c|}
\hline \multicolumn{2}{|l|}{ Behavioral Intention Statistics } \\
\hline & & $\begin{array}{l}\text { Intend to use } \\
\text { the system }\end{array}$ & $\begin{array}{l}\text { I predict I would use } \\
\text { the system }\end{array}$ & $\begin{array}{l}\text { I plan to use the } \\
\text { system }\end{array}$ & $\begin{array}{l}\text { I intend to } \\
\text { consult } \\
\text { balance } \\
\text { my }\end{array}$ & $\begin{array}{l}\text { I intend } \\
\text { to } \\
\text { perform } \\
\text { a transfer }\end{array}$ \\
\hline N & Valid & 313 & 312 & 313 & 313 & 313 \\
\hline Median & Missing & 0 & 1 & 0 & 0 & 0 \\
\hline Mode & & 4 & 5 & 5 & 5 & 5 \\
\hline
\end{tabular}

Note. N-Number of responses; Response measurements, 1-strongly disagree, 2-Dis -agree, 3-Neutral, 4-Agree and 5-strongly agree.

One of the factors relating to Behavior Intention is whether the Client intend, plan or will actually use the system in the near future. As shown in the table above regarding Behavior Intention the respondent actually intend to use the system with a mode of 5 strongly agreeing for all the 5 questions and a median of 5 for the four questions and 4 for one of the questions.

From the above tests for e-banking adoption it can be concluded that performance expectancy, effort expectancy, facilitating conditions and Behavior Intention have a strong impact on the adoption of e-banking services as highlighted by the other researchers. On the contrary for this research Social Influence is non-significant to the adoption of e-banking services as respondents demonstrated that they are not influenced by societal expectation.

\section{Discussion}

Based on the UTAUT model the study aimed at exploring the influence of performance expectancy (PE), Effort Expectancy (EE), Social Influence (SI), Facilitating Conditions (FC) and Behavior Intention (BI) in the adoption of e banking services in Zambia. The UTAUT model was empirically tested on 313 survey respondents from 5 main top banks in Zambia. The findings provide an almost overall support of the UTAUT factors model. The analysis of the study proved that performance expectancy, effort expectancy, facilitating conditions and behavior intentions influence the user's behavior intention to adopt Internet Banking this is in line with the finding of other scholars (Venkatesh et al., 2013; Mwiya et al., 2017; Huang and Kao,2014). However, contrarily to the views of others scholars (Venkatesh et.al, 2003), (Mborokoh, 2015) and (Huang and Kao,2014), for the Zambian context Social Influence was found to be a non-significant factor in the adoption of the banking services which was found to be in support of other studies like (Naranjo-Zolotov and Oliveira,2018).

Table 6. Adoption factor modes

\begin{tabular}{|l|l|l|l|l|l|l|}
\hline Factor Mode & Q1 & Q2 & Q3 & Q4 & Q5 & Interpretation \\
\hline Performance Expectancy & 5 & 5 & 5 & 5 & - & Significant \\
\hline Effort Expectancy & 4 & 4 & 5 & 5 & - & Significant \\
\hline Social Influence & 3 & 4 & 2 & 2 & 2 & In-significant \\
\hline Facilitating Conditions & 5 & 5 & 4 & 4 & 4 & Significant \\
\hline Behavior Intention & 5 & 5 & 5 & 5 & 5 & Significant \\
\hline
\end{tabular}

Note. Response measurements, 1-strongly disagree, 2-Dis -agree, 3-Neutral, 4-Agree and 5-strongly agree. 
Based on the results of the study in the above, the researcher concludes that the UTAUT model is applicable in the Zambian context in determining the factors that affect the adoption of e-banking services. From the analysis of the study PE, EE, FC and BI positively contribute to the user's intention to adopt technology. However, it was noted that SI was an insignificant factor in the adoption of technology.

The aim of this research, as earlier stated is understanding the factors that influence e-banking adoption thereby recommending solutions that will increase the e-banking services adoption by Clients in Zambia. This has been achieved through the realization of the findings of the adoption drivers and adoption barriers.

\section{Limitations of Research}

Like any research, this study also encountered some limitations. Limitations of the study refers to those factors of reserach design or methodology that can influence the interpretation or application of the findings of the study (Yin 2009). Data quality constraints associated with quantitative research are highlighted by (Saunders et al. 2012) as prone to misinterpretation, difficulties in getting indepth information,tends to be artificial and requires high levels of literacy by repondents.

The method of sampling used non probability sampling(purposive sampling) which is prone to the following limitations; sample may not be a representation of the population, samples are likely to be prone to errors thus limiting the generalizability of the findings.

The research is purely descriptive there is therefore need to scientifically test the variables to determine the relationship of the independent and dependent variables.

\section{Recommendation}

From the results of the study, as well as the research gaps noted in the literature review, the following recommendations are made:

Products designed must be user friendly to help Clients to be able to use the platform with so much ease. Technical disruptions should be minimised in order to gain the confidence and trust of the Clients. System downtime/challenges may lead to Clients avoiding the system completely. Banks will need to promote the variable factors that drive the adoption of e-banking as identified in the study by ensuring that products on the Internet Banking platform are beneficial and useful, tailored to the specific requirements of the Clients general needs.

\section{Opportunities for Future Research}

Considering the findings of this study as well as limitations highlighted some further research should be carried out in order to gain a deeper insight into the topic. Further studies could include:

A study can be undertaken to cover other regions other than Lusaka to understand if the results are applicable across Zambia. A mixed method study approach can be selected for future research as current research has made use of a quantitative approach and results may be limited.

Using a similar research structure, the research can be done using other technology models and theories.

A research can be done to explain the barriers hindering the adoption of e-banking services. More research is needed on the impact of MNO's and Fintech on the bank's operations.

\section{Acknowledgments}

The authors wish to acknowledge the valuable support of every one who helped in the actual distribution of the questionnaire and the respondents of the questionnaire. Special appreciation goes to Mulenga Kasonde who helped with the data capture.

\section{References}

Ajtene, A. (2014). Acceptance of E banking services from small and medium enterprses.

Ali Tarhini, M. E. M. (2016). Extending the UTAUT model to understand the customers' acceptance and use of internet banking in Lebanon: A structural equation modeling approach. Information Technology \& People, 29(4), 830-849. https://doi.org/10.1108/ITP-02-2014-0034

Ali, T. A. (2015). Innovation Diffusion Theory Review \& Scope in the Study of Adoption of Smartphones in India. " Journal of General Management Research, 3(2), 101-118.

AlKailani, M. (2016). Factors Affecting the Adoption of Internet Banking in Jordan: An Extended TAM Model. Journal of Marketing Development and Competitiveness, 10(1). 
Al-Smadi, M. O. (2012). Factors Affecting Adoption of Electronic Banking: An Analysis of the Perspectives of Banks' Customers. International Journal of Business and Social Science, 3(17), 295-309.

Anurag Pahuja, S. V. (2015). An empirical Analysis of factors affecting the adoption of E-banking services. Journal of Commerce and Accounting Research, 1(2), 38-45.

Basel Committee on Banking Supervision (2003). Risk management principles for electronic banking, Switzerland: Bank of International Settlements. Retrieved from http://www.bis.org/publ/bcbs98.pdf

Bitner, M. J., Brown, S. W., \& Meuter, M. L. (2000). Technology infusion in service encounters. Journal of the Academy of Marketing Science, 28(1), 138-149.

Bultum, A. G. (2014). Factors Affecting Adoption of Electronic Banking System in Ethiopian Banking Industry. Journal of Management Information System and E-commerce, 1(1), 1-16.

Carolina Martins, T. O. (2014). Understanding the Internet Banking Adoption: A Unified Theory of Acceptance and Use of Technology and Perceived Risk Application . International Journal of Information Management, $34(1), 1-13$.

Creswell, J. (2009). Research Design: Qualitative, Quantitative, and Mixed Methods Approaches (3rd ed.). California: Sage Publications.

Department, M. O. (2017). National Financial Inclusion Strategy 2017-2022. Lusaka.

Featherman, M. S. (2003). Predicting e-services adoption: a perceived risk facets perspective. International Journal of Human-Computer Studies, 59(4), 451-457.

Hussain, Z., Das, D., Bhutto, Z.A., Hammad-u-Salam, M., Tal-pur, F., \& Rai, G. (2017) E-Banking Challenges in Pakistan: An Empirical Study. Journal of Computer and Communications, 5, 1-6. https://doi.org/10.4236/jcc.2017.52001

Ismail, L. B. (2017). The Impact of Online Banking of Customer Satisfaction in Jordan. The International Journal of Organizational Studies \& Innovation, 4(2).

Kao, C. Y. H. S. (2015). UTAUT2 Based Predictions of Factors Influencing the Technology Acceptance of Phablets . DNP, Hindawi Publishing Corporation Mathematical Problems in Engineering, 23.

Kumbhar, Vijay. (2011). Service quality perception and customers' satisfaction in internet banking service: a case study of public and private sector banks. Cyber Literature. 4. 21-30.

Lai, P. (2017). The literature review of technology adoption models and theories for the novelty technology. Journal of Information Systems and Technology Management, 14(1), 21-38. https://doi.org/10.4301/S1807-17752

Lee, Y. K. (2003). The technology Acceptance Model: Past present and future. Communication of the AIS, $12(50), 752-780$.

Lin, F.-T. W.-Y. (2015). Internet banking adoption in a developing country: an empirical study in Vietnam. Information Systems \& e-Business Management, 13(2).

Lusaya and Kalumba (2018). The study of the challenges of adopting the use of e-banking to the customers: The case of Kasama district Banking customers.

Mallika, S. a. (2015). An Empirical Study of Rural Customer's Satisfaction and Consumer Awareness From E-Banking in India With Special Reference to Brahmavar. International Journal in Commerce and Management, 6(5).

Mbrokoh, A. S. (2015). Exploring the factors That Influence Internet Banking Adoption in Ghana. Journal of Internet Banking and Commerce.

Mwiya, B. C. (2017). Examining Factors Influencing E banking Adoption: Evidence from Bank customers in Zambia. American Journal of Industrial and Business Management, 741-759 https://doi.org/10.4236/ajibm.2017.76053

Nor K Md., B. M. (2011). A Model for Analysing the Determinant Factors of Adoption E-Banking Services by Romanian Customers. Economic Computation and economic cybernetics studies and research/Academy of Economics studies.

Nuwagaba and Ngoma. (2014). Digital Banking in Zambia report. 
Oliveria, M. N. Z. (2012). Citizens Intention to use and recommend e-participation: Drawing upon UTAUT and citizen empowerment. https://doi.org/10.1108/ITP-08-2017-0257

Safeena, R. K. (2013). Assessment of Internet Banking Adoption: An Empirical Analysis. Arabian Journal for science and Engineering, 39, 873-849.

Saunders, M. L. (2012). Research methods for business students (6th ed.). Harlow, UK: Pearson Education Limited

Spaho, A. G. (2013). Electronic Banking Adoption and Use in Albania: An Empirical Study . International Journal of Science, Innovation \& New Technology, 1(8). https://doi.org/10.5901/jesr.2014.v4n4p460

Venkatesh, V. M. (2003). User acceptance of information technology: toward a unified view. MIS Quarterly, 27(3), pp. 425-478.

Vinayek, R. a. (2013). Drivers of customer adoption of e-banking: An empirical investigation. Journal of Marketing Vistas.

YIN, R. (2009). Case study research: Design and methods. Sage Publications.

Yousafzai, S. (2012). A literature review of theoretical models of Internet banking adoption at the individual level. Journal of Financial Services Marketing , 17(3), 215-226.

Yu, C. S. (2012). Factors Affecting Individuals To Adopt Mobile Banking: Empirical Evidence From The UTAUT Model. Journal of Electronic Commerce Research, 13(2), 104-121.

ZICTA. (2015). ICT Survey Report - Households and Individuals: Survey on access and usage of Information and Communication Technology by households and individuals in Zambia. Lusaka.

\section{Copyrights}

Copyright for this article is retained by the author(s), with first publication rights granted to the journal.

This is an open-access article distributed under the terms and conditions of the Creative Commons Attribution license (http://creativecommons.org/licenses/by/4.0/). 